\title{
A CONSTRUÇÃO DA AUTOIMAGEM DE CRISTÃO E A FABRICAÇÃO DO HEREGE NAS POLÊMICAS DO SÉCULO XVI
}

\author{
Elaine Cristine SARTORelli* \\ Universidade de São Paulo
}

\begin{abstract}
Resumo. O objetivo deste trabalho é, primeiramente, entender a lógica que preside aos mecanismos da polêmica que atuam nos discursos apologéticos cristãos, e, em seguida, tendo-a compreendido, apontar as estratégias retóricas com que o polemista constrói e valida um ethos de cristão verdadeiro e de "advogado da Verdade" para si, ao mesmo tempo em que fabrica a imagem do "inimigo", o herege, o "falso mestre" para seu adversário. Para isso, comentaremos as técnicas de apropriação de auctoritas praticadas pelo autor ao tratar de si mesmo, e, ao mesmo tempo, os aspectos satíricos da constituição de caricaturas do "outro", quando se visa não apenas à derrisão, mas à exclusão de um adversário. E nós o faremos por meio de um livro "herético", em que o autor, perseguido ele mesmo, reproduz, no entanto, o mesmo processo empregado por aqueles que buscavam instituir uma religião por assim dizer oficial, ou falavam autorizados por ela. Nosso corpus é o livro "herético" Christianismi Restitutio, ${ }_{1}^{1}$ de autoria de Miguel Serveto, publicado em 1553.
\end{abstract}

Palavras-chave. Retórica; ethos; século XVI; polêmicas; Miguel Serveto.

D.O.I. 10.11606/issn.2358-3150.v19i2p20-42

O COMEÇO DO SÉCULO XVI ENCONTROU A IGREJA ROMANA SOB O PONTIFICADO de Alexandre vi, o Bórgia, o qual tinha a fama de conduzir recriações de rituais pagãos em seu palácio; este foi sucedido por Júlio II, o "papa guerreiro", 2 e por Leão x, um Médici que não era sequer sacerdote quando eleito papa. O secretário deste, Pietro Bembo, redigia a correspondência da Igreja com o léxico ciceroniano, ao mesmo tempo em que, segundo se contava, ${ }^{3}$ aconselhava Sadoleto a não ler as epístolas de Paulo, para não corromper

" Doutora em Letras Clássicas pela Universidade de São Paulo (2006).

" Artigo recebido em 05.set.2016 e aceito para publicação em 25.out.2016.

${ }^{1}$ Servetus, Michael. Christianismi Restitutio. Frankfurt: Minerva, 1966 (edição fac-simile da edição de von Murr, de 1790, a qual mantém o texto integral e a mesma paginação da original, de 1553, da qual restam apenas três exemplares).

${ }^{2}$ Entre esses dois inimigos, Rodrigo Bórgia e Giuliano dela Rovere, houve o curto pontificado de Francesco Piccolomini, conhecido como Pio III, de apenas 27 dias.

${ }^{3}$ Tuck 1993, 16. 
seu estilo... Ambos chegaram mesmo a reunir em Roma uma sociedade de literati em que só era possível ingressar pelo voto de jamais usar palavras latinas que não tivessem sido empregadas por Cícero, ${ }^{4}$ vetando assim todo o vocabulário cristão. Mas mesmo a sátira corrosiva de Erasmo ainda não era considerada perigosa, e o prestígio do humanista holandês parecia crescer na medida em que fustigava os costumes e a hipocrisia do clero. Algo, entretanto, começava já a trincar a pretendida e alegada unidade da Igreja, construída à custa de tantas polêmicas e assegurada após uma longa história de combate a dissidências e heresias, em guerras cujas armas foram os dogmas, mas também as cruzadas, fogueiras e torturas. E esse perigo, que a corroeu de dentro, vinha precisamente daqueles que mais procuravam preservá-la; pois foi devido ao trabalho de humanistas que tinham como objetivo depurar a Bíblia de interpolações tardias e recuperar o sentido primitivo das escrituras por meio de estudos filológicos nas línguas bíblicas originais, que uma onda reformista começou a se impor. Contestar escolhas feitas por Jerônimo e apontar os erros deste em sua edição da Vulgata significava também denunciar as consequências desses equívocos, e várias práticas permitidas e estimuladas pela Igreja viriam a ser expostas como antiescriturísticas. Mas, se Erasmo não pretendia senão coibir abusos, a meta de Lutero era negar a autoridade do Papa e abolir a hierarquia eclesiástica, ao suprimir os intermediários entre o homem e Deus. Além disso, nesse momento em que, pela primeira vez, havia circulação em grande escala do livro impresso, o monopólio romano sobre as escrituras foi quebrado, primeiro pela divulgação destas, e depois também por suas traduções para as línguas vernáculas.

No entanto, a Reforma, que desafiou Roma em vários pontos, deteve-se, contudo, diante de outros tantos, que permaneceram intocáveis. Dogmas como a Trindade e o batismo infantil foram mantidos a salvo de especulações graças a interpretações bastante livres das escrituras. Mas a mesma onda reformista, de inspiração depuradora e motivação filológica, atingiu a Reforma mesma logo em seus primeiros anos. Logo surgiram outros reformadores, chamados "radicais", que insistiram em confrontar também aqueles dogmas que, por tradição, haviam permanecido intocados. Assim, enquanto as igrejas reformadas, na qualidade de novidade perigosa a ser combatida, ainda confrontavam a tradição romana, uma nova cisão surgiu em países já reformados, ameaçando-os de dentro. Esses movimentos, embora não totalmente homogêneos, compartilhavam, no entanto, alguns princípios fundamentais, que permitiram que seus estudiosos os reu-

${ }^{4}$ Scott 1991, 22.

Let. Cláss., São Paulo, v. 19, n. 2, p. 20-42, 2015 
nissem sob a denominação hoje consagrada de Reforma Radical. ${ }^{5}$ Herdeiros dos movimentos milenaristas da Idade Média, mas também do zeitgeist do XVI, de retorno às fontes antigas e depuração do cristianismo dos excessos que, segundo acreditavam, lhe haviam sido acrescentados posteriormente, esses grupos propunham já não uma reforma, mas uma restituição da Igreja a uma pureza que acreditavam que ela havia tido em seus tempos primitivos. $^{6}$ Aqui, faz-se necessário ressaltar que essa restitutio era, a um só tempo, dedicada ao passado e voltada para o futuro. Ao passado, porque se tratava de tomar o cristianismo ao pé da letra, tal como acreditavam que este havia sido em tempos apostólicos primitivos, e purgá-lo de outras "novidades", introduzidas posteriormente; e ao futuro porque, com isso, visavam a preparar o Milênio prometido aos justos.

O mais numeroso grupo radical era o dos anabatistas, os quais se opunham ao batismo infantil e, na tentativa de recriar o cristianismo evangélico primitivo, proibiram o porte de armas e instituíram a comunhão de bens. Acreditavam que, assim, chegariam a implantar a Igreja verdadeira, a qual não era uma irmandade espiritual espalhada pelo mundo, mas uma comunidade real, temporal e, portanto, histórica. Sua proposta, em muitos pontos, não distava de uma revolução e, em outro lugar, estudamos seu caráter utópico. ${ }^{7}$

Segundo Norman Cohn (1981, 11), movimentos milenaristas compartilham a mesma doutrina de salvação, a qual é sempre e necessariamente coletiva; terrena; iminente; total; e miraculosa. Em outras palavras, ela, que alcançará toda a comunidade, há de realizar-se neste mundo, em breve, e há de transformar substancialmente a vida na Terra. Tal definição de salvação, essencialmente comunitária, pode ser aplicada aos anabatistas radicais, mas se afasta completamente da sola fide e ainda mais da predestinação protestantes, que podem até mesmo prescindir das boas obras. A redenção anabatista, por sua vez, era ativamente engajada e mesmo militante na vida comunitária, exigindo obras e também provas, dentre as quais figurava o martírio.

O texto bíblico que serve de inspiração para a restitutio encontra-se nos At 3: 21. Ali, Pedro assegura que Cristo será novamente enviado, mas, antes, "é necessário que o céu o receba até que se cumpra o tempo da restituição de

${ }^{5}$ The Radical Reformation, título do ensaio monumental que George H. Williams publicou em 1962 pela Westminster Press.

${ }^{6}$ A restitutio era um método e um programa. Vários livros de inspiração anabatista trazem em seu título a palavra-chave de seu sistema: Johan Campanus, em 1531; Bernhard Rothmann, o líder espiritual de Münster, em 1534; David Joris, em 1542; Guillaume Postel, em 1552; Serveto, em 1553; e, em 1560, Dirk Phillips.

Sartorelli, Elaine C. "Elementos utópicos na restitutio de Miguel Servet". In Nakládalová, ed. 2013, 97-114. 
todas as coisas". Esse tempus restitutionis omnium era o cerne do imaginário radical, mas não estava ausente das fantasias quinhentistas em geral. O próprio Lutero confessou que temia não ser capaz de concluir sua tradução da Bíblia "a tempo". ${ }^{8}$ E Melanchthon demonstrou ter compreendido o potencial propagandístico dessa atmosfera de expectação quando, por causa de uma grande conjunção planetária que havia ocorrido em 1484, a partir da qual se esperavam eventos extraordinários, tentou convencer Lutero a afirmar que havia nascido nesse ano, quando ele, na verdade, nascera em $1483 .{ }^{9}$

\section{O ENVIADO}

Primeira religião fundamentada na conversão, o Cristianismo se organizou desde o princípio sobre a ideia de que era necessária a execução vicária de uma incumbência (a transmissão da mensagem revelada) de cujo sucesso depende a salvação de todos. Nas palavras de Klaus Berger (1998, 236), o "instituto jurídico da missão" daquele que é enviado é “o princípio organizacional das relações entre Deus e o homem, e entre o homem e seu semelhante no Cristianismo". A mensagem que ele traz anuncia e prepara o Reino, e, se seu anseio pela catequização de todos revela o caráter universalista da religião da boa nova, mostra, por outro lado, uma propensão para a unanimidade que a leva a excluir, e eventualmente a eliminar, os reticentes. Lançar uma convocação à cristandade implica engajar a todos em uma causa; aquele que recusa sua adesão a esse chamamento em tempos de crise, como nos tempos primitivos das grandes perseguições e no século XVI, é imediatamente acusado da mais alta traição.

No começo da Idade Moderna, a flagelos conhecidos, como guerras e epidemias, acrescentaram-se novos sobressaltos, como a descoberta da América e o surgimento da sífilis, que Lutero comparava à peste..$^{10} \mathrm{~A}$ estes viriam somar-se ainda a Reforma, a expansão otomana na Europa sob Solimão I e o saque de Roma em 1527. Tais acontecimentos, interpretados como indícios do fim iminente, geraram uma sensação de urgência apocalíptica similar àquela dos primeiros séculos que acabou por se impor quase por toda parte, e unanimemente entre os radicais. Para estes, a própria severa perseguição que sofriam certamente parecia uma prova a mais de que o tempus havia chegado.

\footnotetext{
${ }^{8}$ Klaassen 1992, 21.

${ }^{9}$ Klaassen 1992, 80.

${ }^{10}$ Klaassen 1992, 22.
} 
Em momentos de crises e fraturas, o orador costuma revestir-se do aspecto do profeta, o qual, por sua vez, assume seu duplo papel: o de voz que clama no deserto, por um lado, e o do mensageiro do futuro contra o desespero do presente, por outro. Da mesma forma, profetas levantam-se em épocas de dominação e perseguição por outro povo, considerado idólatra, ou de exílio. A equação se apresenta, então, sob a seguinte forma: tal como havia ocorrido com os profetas do Antigo Testamento e com os mártires cristãos sob Roma, os radicais estavam, agora, sob a tirania da meretriz da Babilônia e do Dragão, o Papa, que sempre haveriam de perseguir os justos. Essa linguagem metafórica e associativa tem grande poder simbólico para aqueles que são levados a verem-se a si mesmos como os únicos cristãos verdadeiros, oprimidos por um reino maligno que agora são chamados a combater.

Tendo como pano de fundo um panorama de circunstâncias históricas difíceis, interpretadas como sinais, o pregador milenarista responde às perguntas "por que" e "para que" escrever com um "esquema de revelação" ${ }^{\prime \prime 1}$ : é chegada a hora de um segredo oculto ser desvendado, primeiramente pelos eleitos e finalmente revelado aos demais. Aqui, o autor cristão assume seu papel de nuntius, o porta-voz imbuído de um mandato. Suas palavras não são pois meros discursos, mas kerygma, proclamação da Verdade revelada. Investido de uma missão que lhe foi confiada, o nuntius reivindica não o direito mas o dever de falar, uma vez que deve revelar algo de que dependem as condições para o desdobramento futuro do plano de Deus para os fiéis. Segundo essa lógica interna, crises são necessárias, uma vez que essa fala só se justifica por completo em momentos de fraturas, nos quais ele, o orador, se posiciona como guia rumo ao futuro prometido.

Esse tipo peculiar de construção ética foi muito utilizado na Reforma Radical. Para que possamos acompanhar a argumentação dos autores aqui mencionados, é preciso ter mente o ponto fundamental de que alguns radicais, dentre os quais Serveto, acreditavam que o mal havia se apoderado da Igreja em 325, no Concilio de Niceia, quando se deu a união do poder temporal ao espiritual. A primeira consequência que temos aqui, então, é que, se os radicais negam tudo o que adveio depois de Niceia, negam não apenas Roma, a tradição escolástica e a organização monacal, mas também boa parte do corpus christianum. E, sem poder contar com a autoridade de uma instituição que lhes emprestasse legitimidade, os radicais, que eram uma comunidade marginal e perseguida, tinham como justificativa mesma que sustentava e validava sua fala a de que ela era a voz do profeta, a qual se encontrava integrada em um contexto de crise que a explicava, em um cenário

${ }^{11}$ Berger 1998, 245.

Let. Cláss., São Paulo, v.19, n. 2, p. 20-42, 2015 
milenarista. Se o papel do orador como tal é aqui, de acordo com a premissa seguida por ele mesmo, quase "incidental", 12 por outro lado sua autopercepção como alguém de importância decisiva é diametralmente oposta. ${ }^{13}$ Para reafirmá-lo, o enviado descreverá os sinais da destruição iminente em um cenário de desolação, valendo-se da associação entre eventos históricos que lhe são contemporâneos àqueles simbólicos, extraídos de trechos bíblicos. Nesse mesmo sentido, a própria perseguição de que os radicais eram vítimas era compreendida como atualização de outras, dos tempos primitivos da Igreja, e revertida a seu favor, como uma prova, no sentido jurídico, de que seus inimigos temiam que a mensagem profética pudesse ser revelada.

O polemista cristão que se posiciona como profeta é também um tipo particular de historiador de uma "História do futuro", na expressão exemplar de Vieira. O passado, entendido como prefiguração, é submetido a um processo de ressignificação, e o que aconteceu é interpretado em uma relação especular com aquilo que "se cumpriu" ou que ainda há de acontecer. Da mesma forma, também o presente é disposto segundo uma classificação em que os eventos sejam compreendidos como "sinais dos tempos", indícios da iminência de um fim já esperado e mesmo ansiado. Tendo em mente uma profecia, ou seja, partindo-se de algo futuro para interpretar o presente, faz-se o catálogo dos acontecimentos contemporâneos que comprovam o que há de vir. Nessa História significativa, aquele que constrói sua imagem como profeta e mártir insere-se frequentemente com um duplo testemunho: o de seu discurso e o de sua própria perseguição e morte. Assim, os radicais anabatistas produziram uma História que, tendo como ponto de partida o extermínio em massa de que foram vítimas no século XVI, recuou até os primórdios do cristianismo para traçar uma verdadeira árvore genealógica do martírio cristão, de Estevão aos anabatistas. Esse livro, O Espelho dos Mártires, ${ }^{14}$ tão gigantesco em tamanho quanto em esforço

\footnotetext{
${ }^{12}$ Kennedy 1998, 122.

${ }^{13}$ A questão que de seu próprio ponto de vista se impõe aqui é então a que diz respeito à eleição de um homem em especial como receptor e transmissor da Verdade, o qual precisa construir para si a credibilidade de poder se apresentar como enviado de Deus antes que a profecia que ele traz se realize. O Prólogo do Apocalipse é exemplar e paradigmático desse tipo de construção ética. Deus confiou a Cristo a revelação das coisas que deveriam acontecer em breve, para que este a mostrasse aos seus servos. E Jesus a comunicou, por meio de seu anjo, ao seu servo João. Seria interessante estudarmos a euidentia como figura empregada para descrever visões proféticas, mas nossa intenção aqui é apenas mostrar que João dá testemunho de que tudo quanto viu é palavra de Deus. "Feliz aquele que lê e aqueles que escutam as palavras da profecia e também põem em prática o que nela está escrito. Pois o tempo marcado está próximo" (Apc 1, 1-13).

${ }^{14}$ Van Braght 1977. The Bloody Theater or Martyrs Mirror of the defenseless Christians who baptized only upon confession of faith, and who suffered and died for the testimony of Jesus, their Saviour, from the time of Christ to the year A.D. 1660 (translated from the original Dutch language from the edition of 1660 by Joseph F. Sohm).
} 
interpretativo, é um martirológio e também uma ars moriendi. Nessa História plena de sentido, porque totalmente voltada para seu fim, os radicais afirmam desempenhar um papel fundamental: uma vez que "o prazo se cumpriu", é preciso restaurar o cristianismo primitivo, o único verdadeiro, a fim de que essa restituição do passado possibilite o novo Advento.

\section{OS MECANISMOS DA POLÊMICA RELIGIOSA}

Defendemos que a estratégia de legitimação do radical passa necessariamente e antes de tudo pela exploração do ethos de perseguido e, por conseguinte, pela polarização com um "outro", o qual, sendo frequentemente o porta-voz da ordem vigente, representará o papel de perseguidor. Seus discursos, pois, são abundantes de marcas de afastamento e rompimento, de recusa e ruptura: "nós" não somos "eles", sendo que "eles" são os poderes constituídos, a Igreja, o Estado, a sociedade "mundana". A seguinte, forçosamente ligada a esta primeira, é que a justificativa mesma que sustenta sua fala é de que se trata da voz do profeta. Esta é a voz moralizante do justo, perseguido por um Império cujo poderio sua mensagem ameaça, e também, ao mesmo tempo, aquela que se encontra integrada num contexto de crise política ou religiosa que a explica; frequentemente, um contexto milenarista, em que a promessa de libertação do jugo da servidão se soma a esperanças de vir a representar um papel principal na nova ordem que se há de instaurar. A estratégia de apresentar-se como o mensageiro a uma comunidade em perigo implica a necessidade de inverter a perseguição a seu favor, tornando-a uma comprovação de sua justiça diante de inimigos que temeriam que a mensagem que o profeta traz pudesse ser revelada. Por isso, ao mesmo tempo em que dados da realidade são tomados como comprovação de que a profecia está por se realizar, é preciso que, discursivamente, seja apresentado como que um pano de fundo apocalíptico que justifique a convocação para a batalha que a fala do profeta traz.

É preciso ter em mente ainda que um polemista envolvido em debate religioso advoga pela existência de uma verdade, a Verdade, a qual, para ele, é prévia e revelada e, assim, admitida como exterior ao discurso, e não tramada intradiscursivamente, como na Retórica clássica. Apresentando-se como porta-voz de uma mensagem que, segundo ele mesmo, não é criação sua, promove seu apagamento como autor do discurso, insistindo em que ele não é senão um veículo para a mensagem que traz. E, para conseguir legitimar seu ethos de enviado, ele, que não reivindica para si autoria, mas testemunho, deve, ao mesmo tempo, marcar sua originalidade com respeito 
a todos os outros intérpretes da Escritura a que se contrapõe e, por outro lado, investir-se de características já aceitas por aquela comunidade, preenchendo suas expectativas. Ele deve se parecer com a imagem que aquela comunidade tem de um profeta.

Mas vamos retomar essas questões e exemplificá-las com um homem do século xvi que foi considerado herege em todos os pontos dogmáticos: o espanhol Miguel Serveto. Condenado à morte entre os católicos, foi finalmente queimado vivo em Genebra, e sua fogueira, a primeira em terras protestantes, gerou uma discussão que culminou num diálogo em que Sebastien Castellion respondia ponto por ponto às acusações que Calvino havia utilizado para justificar a condenação de Serveto. Esta resposta de Castellion ${ }^{15}$ é hoje considerada a primeira tentativa, na História ocidental cristã, de defesa do direito de divergir e errar sem que isso signifique a condenação à morte, e, por isso, é tida como precursora da Declaração Universal dos Direitos Humanos naquilo a que hoje se dá o nome de liberdade de consciência.

Apontaremos apenas alguns poucos dos muitos componentes do discurso servetiano que poderíamos analisar. Primeiro, é preciso saber que Serveto escreve a fim de, em linguagem marcadamente milenarista, apresentar suas "provas", extraídas do AT e do Apocalipse, de que já se haviam passado os 1.260 anos antes do final dos tempos. É chegado o momento da batalha, e Serveto a prepara denunciando, com seu livro, o poder da "antiga serpente" que se apoderou da Igreja. É para essa guerra de proporções cósmicas que Serveto, autoproclamado nuntius da mensagem e comandante dos exércitos do Bem na luta contra o Mal, lança sua uocatio, a convocação a todos os cristãos para se deixem guiar por ele, o novo Miguel. A intenção é mover uma guerra santa contra Roma, mas também contra os "novos gnósticos" (aqueles que postulam o servo-arbítrio e a predestinação) e refundar a Igreja.

\section{MIGUEL, PEDRO E IRINEU}

Tendo causado uma verdadeira tempestade com dois pequenos livros juvenis de conteúdo antitrinitário, ${ }^{16}$ o espanhol Serveto, que já havia conseguido escapar da Inquisição mais de uma vez, vivia desde havia muito na França católica sob a falsa identidade de Michel de Villeneuve. Em 1553, a

${ }^{15}$ Tendo publicado sob pseudônimo De haereticis an sint persequendi, em 1554, escreveu também Contra libelli Calvini in quo ostendere conatur Haereticos iure gladii coercendos esse, o qual circulou anonimamente e de forma clandestina, sendo publicado postumamente.

${ }^{16}$ De Trinitatis Erroribus libri septem, de 1531, e Dialogorum de Trinitate libri duo, de 1532. 
despeito de sua prestigiosa posição de médico do arcebispo de Vienne do Delfinado, expôs-se à prisão e à morte ao mandar instalar secretamente uma prensa a fim de publicar o incendiário Christianismi Restitutio, "caso de heresia total", ${ }_{17}$ em que conclamava todos os cristãos a uma batalha para expulsar o Anticristo de Roma. E ele o fez, segundo diz, não para sua glorificação pessoal, mas porque havia percebido pelos "sinais" que o final dos tempos estava próximo, e ele não podia esconder a lâmpada debaixo da mesa, como na parábola bíblica. Que ele estivesse plenamente convencido de seu papel messiânico, comprova-o o fato de que não apenas morreu por suas convicções, mas parece mesmo ter buscado o confronto que o levou à fogueira. ${ }^{18}$

Serveto, em consonância com o programa radical, propõe-se conclamar a todos os fieis para a restituição da Igreja, fugata desde Niceia. Assim, também ele apresenta seu "esquema da revelação", alegando que seu direito à fala deveria ser garantido não porque o beneficiava, mas porque dele depende o futuro de todos. Cristo é ao mesmo tempo o fiador de seu discurso e aquele por cuja causa ele luta, por quem advoga.

Serveto, assim como todos os demais radicais da época, estava envolvido em cálculos para definir a data do fim deste mundo e do advento do Milênio. E, com toda a Reforma Radical, ele o esperava para breve e acreditava que ele seria possibilitado por uma batalha celestial, na qual, segundo o Apocalipse, Miguel combateria os anjos do mal. Essa guerra tem sua contrapartida terrena e humana, e aí Serveto pretende desempenhar um papel fundamental, não só como intérprete veraz dos signa que comprovavam que o prazo estava por se encerrar (completum tempus), mas também como verdadeiro (e literal) general dos exércitos do bem. Os argumentos com que se autoriza afirmar isso estão construídos sobre a tradição apocalíptica em sua vertente milenarista e são solidamente demonstrados e tecidos com grande lógica intrínseca ao longo de uma obra de quase oitocentas páginas. Não deixa, porém, de aduzir como prova o fato de que seu nome era Miguel... E, como havia nascido em 29 de setembro, dia de São Miguel, escolheu essa data para a composição da primeira página de seu livro, na qual constavam os seguintes versículos bíblicos: "e havia guerra no céu, Miguel e seus anjos lutavam contra o dragão". Por isso, a associação por excelência a que recorre para criar uma imagem de si em seu discurso e validar sua posição de sol-

\footnotetext{
${ }^{17}$ Friedman 1978.

${ }^{18}$ Tendo sido encarcerado na França católica, para "investigação" acerca da autoria do livro herético publicado anonimamente, Serveto conseguiu escapar da prisão, para reaparecer, três meses depois, na Genebra teocrática de Calvino. Ali foi novamente aprisionado, levado a julgamento e finalmente queimado. Segundo Calvino e seu colaborador Farel, Serveto poderia ter escapado à morte por fogo lento se tivesse concordado em pronunciar a fórmula "filho eterno de Deus", em vez da servetiana "filho do Deus eterno".
} 
dado de Cristo, fundamental em toda a sua doutrina, é a associação de sua própria pessoa com as características do guerreiro Arcanjo Miguel...

Dessa forma, Serveto vincula seu nome e sua imagem a tudo aquilo que o imaginário coletivo atribuía ao Arcanjo guerreiro, investindo-se da armadura, da lança, da espada de Miguel. Assim, quando o leitor imaginava um Serveto, tendia a lhe emprestar as características com que a iconografia havia representado o arcanjo, e essa era uma estratégia bastante eficiente para investir-se daquilo que pertencia ao modelo, inclusive sua missão (a de libertar-nos do Mal). Como seu onomástico, ele se posicionava à frente de um exército de libertação cuja missão era combater a ímpia Babilônia e restituir o cristianismo verdadeiro, preparando a batalha final. É para essa guerra que ele lança sua uocatio, a convocação a todos os cristãos para se deixem guiar por ele, o novo Miguel. A intenção é mover uma guerra santa contra Roma, mas também contra os "novos gnósticos" (aqueles que postulam o servo-arbítrio e a predestinação) e refundar a Igreja. ${ }^{19}$

Por isso, outra das estratégias mais empregadas aqui consiste em estabelecer pontes ou comparações entre ele, Serveto, e um nome inquestionável da História cristã, para, assim, se apropriar das qualidades daquele por meio dessa aproximação. Esta tática, bastante eficiente, consiste em agregar autoridade ao próprio discurso ao mostrar-se associado a alguma auctoritas reconhecida por aquela comunidade. No caso de um radical, essa comparação deve ser com um nome da Patrística pré-nicena. Serveto recorre frequentemente a esse expediente; por exemplo, constrói uma ponte com Irineu, aquele que primeiro e mais fortemente combateu hereges. Quando Serveto diz textualmente que os protestantes são "magos" e "gnósticos", está revestindo seus adversários das características dos inimigos de Irineu - e, portanto, está implícito que ele, Serveto, é o próprio. Com ele, tece a alusão intertextual da comparação da esmeralda com a "artística falsificação de vidro". Para distinguir a pedra falsa da verdadeira, se faz necessário um "conhecedor", o qual, entretanto, não possui senão sua pureza.

Mas Serveto recorre também a uma comparação implícita de si mesmo com Pedro, ao apelidar seu adversário-mor, Calvino, de Simão Mago. Ele associa o arquiherege da Samaria ao reformador genebrino com a alegação de que ambos negavam as boas obras e preconizavam a predestinação, mas acrescenta ainda o argumento de que "um rétor era ele, sofista, eloquente,

\footnotetext{
${ }_{19}$ Para explicações mais detalhadas, ver a tese da autora, Estratégias de construção e de legitimação do ethos na causa veritatis: Miguel Servet e as polêmicas religiosas do século XVI. Tese apresentada ao Programa de Pós Graduação em Letras Clássicas, do Departamento de Letras Clássicas e Vernáculas, da Faculdade de Filosofia, Letras e Ciências Humanas da Universidade de São Paulo, para obtenção do título de doutora em Letras. São Paulo, 2005.
} 
disputando para vencer com elegância. O mesmo de que vos incumbis vós todos, que só vos satisfazeis com o lenocínio de um discurso ensaiado!". 20

\section{GENUS HUMILE}

E aqui chegamos àquela outra estratégia de autorização ética do enviado, a qual é ligada à elocutio. A ideia de que a linguagem coloquial e não artística como mais próxima da verdade perpassa toda a literatura cristã. Jerônimo, por exemplo, em seu prefácio da Vulgata, afirmava que o exterior rude da Sagrada Escritura é como se fosse (quasi) um belo corpo (pulchrum corpus) encoberto por uma roupa suja (uestem sordidam). Por outro lado, o combatente de hereges, Irineu, em seu Adversus haereses, acusa os adversários de ocultar a verdade com suas fraudes, a ponto de muitos não serem mais capazes de separar da mentira aquilo que é verdadeiro: "uma pedra preciosa, uma esmeralda, que tem grande valor aos olhos de muitos, perde o seu valor diante de artística falsificação de vidro até não se achar alguém que a examine e desmascare a fraude" ${ }^{21}$ Os exemplos ocorrem a cada linha na literatura cristã, sempre associando a ars dicendi à ars mentiendi.

A afirmação de que talis hominibus fuit oratio qualis uita (Sêneca 114. 1), ao lado da máxima de Quintiliano segundo a qual uir bonus, peritus dicendi, leva ao pressuposto de que é possível ver na aparência do homem a sinceridade de seu discurso. Este se tornou ainda mais importante no cristianismo, e, no interior deste, ainda mais na obra de Erasmo de Rotterdam. Para o humanista holandês, o discurso é auto-expressão sincera e, para se conhecer um homem, dever-se-ia prestar atenção naquilo que escreve, uma vez que sermo hominis verax imago est mentis, e, assim, por meio de sua fala, a pessoa se dá a conhecer de fato e de verdade. Serveto vai por esse mesmo caminho e, tendo afirmado todo o tempo que a fala sofística de seus adversários trai a alma falsa destes, crê ainda que o pecado é capaz de alterar tanto o corpo como a alma do pecador cum insigni pudore, ou seja, com uma vergonha assinalada ou sinalizada, isto é, marcada para ser visível.

Por isso os rostos dos homicidas, dos perversos e dos possuídos pelos demônios costumam transformar-se. ${ }^{22}$

\footnotetext{
${ }^{20}$ Rhetor ille erat, sophista, eloquens, elegantia sua uincere certans. In id quoque uos omnes incumbitis solo dictionis lenocínio saturati. Christianismi Restitutio, p. 674.

${ }^{21}$ Irineu de Lião. Livros I, II, III, IV, V. Coleção Patrística. São Paulo: Ed. Paulus, 1995, 29-30.

${ }^{22}$ Hinc homicidarum, flagitiosorum, et a daemonibus occupatorum solent facies mutari. Christianismi Restitutio, p. 384
} 
Existe pois a crença de que as faltas morais tornam-se visíveis exteriormente. Um herege, portanto, tem aparência de herege, assim como um cor mundum torna-se manifesto numa aparência igualmente limpa e num bom comportamento, o qual, por sua vez, seria a fonte e a prova de um discurso puro e verdadeiro.

\section{O ETHOS DE SERVETO}

Não é ocasião agora de ver todos os elementos com que Serveto constitui seu ethos, mas apresentarei alguns, extraídos especialmente da uocatio e do proemium da Restitutio.

Convocação de toda a Igreja apostólica a suas origens, tendo sido restituído na íntegra o conhecimento de Deus, da fé do Cristo, de nossa justificação, da regeneração do batismo e da ingestão da Ceia do Senhor. Tendo-nos sido restituído, por fim, o reino celeste, e dissolvido o cativeiro da ímpia Babilônia, e destruído totalmente o Anticristo com os seus. ${ }^{23}$

O que aqui se nos impõe é tão sublime por sua grandeza, como fácil por sua evidência e certo por sua demonstração. A maior de todas as coisas, leitor, é conhecer a Deus manifestado substancialmente e Sua natureza divina verdadeiramente comunicada. A manifestação do próprio Deus por meio do Verbo e Sua comunicação por meio do Espírito, ambas substanciais só em Cristo, só em Cristo as discerniremos claramente, de maneira que, no homem, distinga-se toda a deidade do Verbo e do Espírito.

Explicaremos a manifestação divina desde o princípio dos séculos, o grande mistério de piedade fora de discussão: que Deus tenha outrora se manifestado no Verbo e agora na carne; que se tenha comunicado pelo Espírito; que tenha sido visto por anjos e por homens, em visão outrora velada, agora revelada. Exporemos claramente os modos verdadeiros, por meio dos quais Deus se mostrou para nós, visível externamente pelo Verbo e perceptível internamente pelo Espírito, mistério duplamente grande, que o homem veja e possua o próprio Deus. A Deus, antes não visto, nós veremos agora por meio de sua face revelada, e contemplá-lo-emos, reluzindo dentro de nós mesmos, se abrirmos a porta e percorrermos o caminho.

É preciso abrir já essa porta e esse caminho de luz, luz sem a qual nada se pode ver, sem a qual ninguém pode ler as Sagradas Escrituras, nem compreender a Deus, nem tornar-se cristão. Este é o caminho da Verdade: seguro, fácil e sincero, o único que nos franqueia integralmente o conhecimento divino de Cristo no Verbo, a verdadeira perfeição do Espírito Santo, e a mesma substância de um e de outro em Deus e que põe ante nossos olhos o próprio Deus.

${ }_{23}$ VOCATIO. Totius Ecclesiae apostolicae est sua limina uocatio, in integrum restituta cognitione Dei, fidei Christi, iustificationis nostrae, regenerationis baptismi, et coenae domini manducationis. Restitutio denique nobis regno caelesti, Babylonis impiae captiuitate soluta, et Antichristo cum suis penitus destructo. 
(...) Ó Cristo Jesus, Filho de Deus, que nos foi dado do céu e manifestas a deidade tornada visível em ti mesmo, abre-te para teu servo, para que se revele tão grande manifestação. Concede agora teu bom espírito e tua palavra eficaz a quem tos pede, dirige minha mente e minha pena, para que eu possa narrar a glória de tua divindade, e exprimir a verdadeira fé acerca de ti. Tua é esta causa, e és tu que estás explicando tua glória, recebida do Pai, e a do teu Espírito, causa que se me apresentou com certo impulso divino para que dela me incumbisse, uma vez que estava preocupado por tua verdade. Comecei esta incumbência algumas vezes, e agora de novo sou forçado a incumbir-me dela, porque, em verdade, esgotou-se o tempo, como, a partir da evidência do próprio tema e dos sinais manifestos dos tempos, hei de demonstrar agora a todos os fieis. Não se deve ocultar a lanterna, tu nos ensinaste, de maneira que, ai de mim!, se não evangelizar! Trata-se de uma causa comum a todos os cristãos, à qual estamos todos obrigados.

Resta-te, leitor, mostrares-te, em nome de Cristo, benévolo até o fim, e ouvirás tudo na língua da verdade, sem qualquer artifício. ${ }^{24}$

Nossa intenção é mostrar como o autor-missionário oferece uma imagem de si em seu discurso. Aqui, temos, primeiro, que algo se nos impõe, mostrando que se trata de uma tarefa recebida e que ele deve cumprir. Ele é instrumento para a propagação de uma mensagem que não é dele, mas nada menos que a causa de Cristo. Tocado por esse "impulso divino" e em nome da "verdade", cabe-lhe ser "servo" de Cristo, "narrar a glória" e "exprimir a verdade", "explicar" e "expor claramente" - trabalho que é "sublime, fácil e certo" na mesma medida em que o caminho é "seguro, fácil e sincero".

${ }^{24}$ PROEMIVM. Qui nobis hic ponitur scopus, ut est maiestate sublimis, ita perspicuitate facilis, et demonstratione certus: omnium maxima, lector, Deum cognoscere substantialiter manifestatum ac diuinam ipsam naturam uere communicatam. Manifestationem Dei ipsius per Verbum, et communicationem per Spiritum, utranque in solo Christo substantialem, in solo ipso plane discernemus, ut tota Verbi et Spiritus deitas in homine dignoscatur. Manifestationem diuinam a seculis explicabimus, magnum citra controuersiam pietatis mysterium, quod sit Deus olim in Verbo, nunc in carne manifestatus, Spiritu communicatus, angelis et hominibus uisus, uisione olim uelata, nunc reuelata. Modos ueros aperte referemus, quibus se nobis exhibuit Deus, externe uisilem Verbo, et interne perceptibilem Spiritu, mysterium utrinque magnum, ut Deus ipsum homo uideat, et possideat. Deum antea non uisum, nos nunc reuelata facie uidebimus, et lucentem in nobis ipsis intuebimur, si ostium aperiamus et uiam ingrediamur. Aperire iam oportet ostium hoc, et uiam hanc lucis, sine qua nihil potest uideri, sine qua nemo potest sacras scripturas legere, nec Deum intelligere, nec Christianus fieri. Haec veritatis est via, certa, facilis, et syncera, diuinam Christi in Verbo cognationem, Spiritus Sancti veram perfectionem, et eandem utriusque in Deo substantiam, integre sola patefaciens, Deumque ipsum nobis ob oculos ponens. (...) O Christe Iesu fili Dei, qui de coelo nobis datus, deitatem patefactam in te ipsum uisibilem manifestas, teipsum aperi seruo tuo, ut manifestatio tanta uere patefiat. Spiritum tuum bonum, et Verbum efficax, petenti nunc tribue, mentem meam et calamum dirige, ut diuinitatis tuae gloriam possim enarrare, ac ueram de te fidem exprimere. Causa haec tua est, et tuam a patre, et Spiritus tui gloriam explicans, quae diuino quodam impulso tractanda sese mihi obtulit, cum essem de tua ueritate solicitus. Tractare aliquando coepi, et nunc iterum tractare cogor, quia completum est uere tempus, ut ex rei ipsius certitudine, et ex signis temporum manifestis, sum nunc piis omnibus ostensurus. Lucernam non esse abscondendam, tu nos docuisti, ut uae mihi sit, nisi euangelizem. Causa communis Christianis omnibus agitur, cui omnes tenemur. Superest, lector, ut te pro Christo beneuolum usque ad finem exhibeas, et rem totam audies sermone ueritatis absque aliquo fuco. Christianismi Restitutio, pp. 1-4. 
Algo que nos importa diretamente, ao buscarmos sinais de euidentia ou ecfrase, é quão recorrente é a metáfora da luz e da sombra. A primeira associada à verdade e, portanto, ao orador, o qual vê a Deus e explica sua mensagem com clareza, enquanto que seu oposto obviamente se aplica à cegueira do mundo e às trevas infernais. Em Serveto, a encarnação do Verbo tornou possível aos homens a experiência sensorial de Deus, e, por isso, seu vocabulário remete a cada passo ao campo semântico da visão: "ver a Deus", "contemplar a Deus", "Seu rosto desvelado", "caminho da luz", "sem a qual ninguém pode ver nada" e "sem a qual ninguém pode ler as Sagradas Escrituras", as quais colocam Deus "ante nossos olhos"; fala ainda em "cegueira do mundo", enquanto Cristo "manifesta de forma visível a deidade revelada". A metáfora da luz aparece ainda mais plenamente quando ele escreve: "Não se deve ocultar a luz, tu nos ensinaste, de maneira que ai de mim!, se não evangelizar". Ao remeter diretamente à parábola da lâmpada escondida debaixo da mesa, Serveto reafirma sua pregação como missão dada por Cristo, a de ser "exemplo diante dos homens"; e, ao insistir no sentido da visão, assegura a materialidade comprobatória daquilo que ele afirma. Frequentemente ainda, recorre à interpretação dos textos cristãos reafirmando a realidade expressa pelo pronome demonstrativo "este", em "este é o filho de Deus". Para ele, isso denota claramente a presença física, perceptível pelos sentidos, da manifestação divina.

No decorrer do livro, outra oposição vai se desenhando: a verdade é clara e nítida; o sofisma, escuro e nebuloso. Uma é expressa em uma linguagem que se autoproclama direta e cristalina; o outro recorre a tortuosidades e obscuridades vocabulares. A falsidade se perde em névoas que lembram um pesadelo, ou então afundam na areia movediça do campo semântico da loucura. Seus adversários são fascinados ou enfeitiçados (fascinati) e alucinados (hallucinati), e têm ilusões de demônios (illusiones daemonum). Seus ensinamentos são ilusão falaz (fallax illusio), loucura (insania), ilusões metafísicas (metaphysicae illusiones), embuste metafísico (praestigium metaphysicum), fantasias que não existem (phantasias quae non sunt), ilusão mágica e horrível (horribilis atque magica illusio), demência (dementia), delírios (deliria). Para o antitrinitário Serveto, as três pessoas realmente distintas da Trindade nicena são quimeras invisíveis (inuisibiles chimaeras), monstro impossível (impossibile monstrum) e os "trigêmeos Geriões, o tricéfalo Cérbero ou a Quimera de Belerofonte (tergemenos Geryones, tricipitem Cerberum, aut Bellerophontis chimaeram), em descrições que lembram transtornos mentais causados por transtorno mental ou estado alcoólico. Diz, afinal, que seus adversários estão "totalmente ébrios" (penitus ebrii).

No final do Proêmio, ele pede que o leitor permaneça atento até o fim, porque assim vai ouvir tudo "na língua da verdade, sem qualquer artifício". 
Ele usa o termo latino fucus, maquiagem, verniz; em outras palavras, sem retórica. A ideia é de que, se o Espírito Santo não usou de artifícios retóricos para falar, mas antes, ao contrário, preferiu as palavras simples e comuns, assim também o porta-voz da mensagem não deveria se esforçar para falar bem segundo os procedimentos retóricos, considerados sofísticos em bloco, mas sim dizer aquilo que tinha sido enviado a dizer sem rebuscamentos ou preocupações voltadas para o deleite. Para citar apenas um exemplo, dentre inúmeros possíveis, Serveto diz, na sua Apologia a Melanchthon:

Mas o Espírito Santo nunca falou por tais meios. Nunca fez uso de discursos, de artifícios polidos com colorido variado, pois ama o falar simples e comum. Também Paulo ensina que a força da pregação de Cristo é esvaziada pela eloquência do discurso. Logo, vossa retórica afetada e sofística é um indício de que vossa verdade é fraca e conduz a várias armadilhas de falsidade..$^{25}$

Em outro momento, volta a associar a verdade com o discurso de genus humile e o a falsidade com as práticas oratórias dos sofistas.

Reflete, Filipe, nesta única coisa: que eu não induzo a quaisquer novidades no uso dos termos, que eu não emprego nenhum sofisma, que eu não cometo abuso algum quanto às palavras das Escrituras, como vós fazeis. Eu não deturpo nenhum passo da Escritura, a nenhum violento. Tudo sai de mim de forma sincera, simples e aberta. Se tivesses uma migalha de inteligência, isso já seria para ti uma grande prova de veracidade. Ofende-vos que eu fale contra vosso costume. Como se eu não tivesse de ter muito maior cuidado em falar de acordo com as Sagradas Escrituras! A tal ponto estais enfeitiçados por vossos costumes perversos que não vos dais conta de que, para Deus, sois odiosos sofistas. ${ }^{26}$

\section{O FALSO MESTRE}

Serveto reafirma seu ethos também já na primeira linha do Livro Primeiro, quando afirma que vai começar a tratar do tema "em conformidade

\footnotetext{
${ }^{25}$ At spiritus sanctus nunquam per talia organa loquutus est. Nunquam est usus sermonibus, artificis fuco vario politis, cum simplicem amet, et vulgarem sermonem. Paulus quoque docet, ob eloquentiam sermonis inaniri vim praedicationis Christi. Rhetorica ergo affectata et sofistica vestra, imminutionem veritatis arguit, et falsitatis varias adducit illecebras. Christianismi Restitutio, p. 674.

${ }^{26}$ Hoc unum cogita, Philippe, Me nullas uocum nouitates inducere, me nullo sophismate uti, me nullis scripturae vocibus abuti, ut uos facitis. Nullum scripturae locum ego detorqueo, nulli uiolentiam facio. Omnia mihi syncere, simpliciter et plane procedunt. Hoc tibi, si micam intellectus haberes, Magnum esset ueritatis argumentum. Offendit uos, quod contra consuetudinem ego uestram loquor. Quase non sit mihi maior habenda cura, ut cum sacris scripturis loquar. Adeo estis praua consuetudine fascinati, ut non intelligatis, esse uos Deo odibiles sophistas. Christianismi Restitutio, p. 676.
} 
com a pregação primitiva dos apóstolos" e por aquilo "que está claro para qualquer um que esteja em seu juízo e que foi pregado publicamente a todos". Mas, como sempre, não é possível fazê-lo sem "reprimir os sofistas", aqui também chamados de fariseus. A polarização dá-se imediatamente, reproduzindo os embates evangélicos: um apóstolo versus um sofista ou um fariseu.

Esse tipo de comparação entre um "eu" e um "tu" construído como o adversário a ser excluído é constitutivo das polêmicas, as quais se apoiam forçosamente na existência, fabricada discursivamente, de um inimigo. Como não estudamos os dois lados da questão (questão, réplica, tréplica), mas apenas o discurso de um lado, sobre si mesmo e o outro, interessa-nos essa relação especular entre o orador e seu inimigo, que é inerente a esse gênero discursivo. Aqui, o autor parece não ser capaz de mostrar quem ele é sem dizer a quem se opõe e quem é seu inimigo. No caso dos polemistas cristãos, a mais significativa estratégia de controvérsia utilizada para sua apresentação como missionário e advogado da verdade é afirmar que fala apenas a verdade pura e simples, sine fuco et sine sophismate. Sendo assim, chegamos sem dificuldades à conclusão de que, se o nosso orador se apresenta como porta-voz da Verdade única e revelada, há de mostrar seus opositores segundo as características associadas àqueles a que os Evangelhos chamam "falsos mestres". Concluímos então que, segundo a lógica que guia esta argumentação, missionário e herege falam línguas diferentes; aquele se expressa espontaneamente, inspirado, com a simplicidade do cor mundum; este, com a sofisticação de quem tenta ocultar sua sedução sob um discurso lisonjeiro e falso. Assim, o enviado alega que pratica a língua do Espírito Santo, a qual é simples e rude (e o Cristianismo sempre fez grande esforço para transformar seu mau latim em preceito, programa e mesmo moral...), e o falso mestre se expressa, como se pode adivinhar facilmente, por meio do sofisma. O herege será pois mostrado como alguém escreve ou fala artificiose, e escrever artisticamente é aqui sinônimo de falsear e mentir. E, ao aproximar o herege do sofista, o discurso cristão se apropriou e se aproveitou de uma já então longuíssima e vastíssima tradição de repúdio e de ataque aos sofistas, que, como ganho secundário, trouxe ainda a assimilação de si mesmo como alguém vinculado às altas ideias perenes dos platônicos.

Como exemplo desse mecanismo, apresento bem brevemente o começo da Epístola aos Gálatas, escolhido entre dezenas de outros possíveis. Paulo se apresenta ali como apóstolo, "não por iniciativa humana nem por intermédio de nenhum homem, mas por Jesus Cristo e por Deus Pai, que o ressuscitou dentre os mortos" (Gl 1:1), e, tendo feito isso, passa imediatamente a mencionar "certas pessoas" que estão "perturbando" a comunidade e que querem "transtornar o Evangelho de Cristo" (Gl 1:7). Este é o modelo exemplar: o apóstolo dá seu nome, sua função, sua mensagem, 
fala de sua vocação, a qual lhe impõe uma tarefa, que é pregar a verdade e combater os falsos mestres. A premissa da Verdade única condiciona o resultado: um Deus, uma Palavra inequívoca, seu único Filho. A relação com o outro é pois de adesão (do outro a mim, obviamente) ou de exclusão. Não há convivência pacífica de diferenças nem divergência aceitável de opiniões. Logo em seguida, em Gl 1:8, Paulo diz que, se alguém pregasse um Evangelho diferente daquele que ele, Paulo, pregava, que esse tal fosse "maldito", ainda que fosse "um anjo vindo do céu".

\section{A FABRICAÇÃO DO HEREGE}

O herege também é fabricado discursivamente segundo estereótipos, agora negativos, previamente compartilhados pela comunidade cristã. O campo semântico da heresia compõe-se de um léxico fixo e bastante imagético, ao qual se recorre para "descrever" o inimigo: ele é veneno, infecção, peste; e sedução, subterfúgio, ilusão perniciosa, desordem, corrupção. Essas características todas estão associadas e como que dependem da escuridão, ou seja, da ausência daquilo que possibilita a euidentia. O herege, portanto, promove a confusão e embaralha mesmo aquilo que é acessível aos sentidos, a fim de fazer o fiel desviar-se do caminho. No sua Brieve instruction pour armer tous les bons fideles contre les erreurs de la secte commune des Anabaptistes, ${ }^{27}$ Calvino acusa os adversários de procurarem a escuridão para evitar que sua confusão seja descoberta. Diz: "eis, portanto, a razão porque se ocultam em suas cavernas de palavras obscuras e incertas" (voyla donc pourquoy ilz se cachent em ses cavernes de parolles obscures $\mathcal{E}$ douteuses).

Recorre-se também frequentemente a um mecanismo próprio da sátira, a animalização, a qual possui uma eficácia que virá a ser bastante conhecida também dos regimes totalitários: desumanizar o adversário, atribuindo-lhe as características animalescas do burro, do porco, do lobo e da ave de rapina, é privá-lo de alma; compará-lo a ratos ou insetos prepara o terreno para sua eliminação. Tratados heresiológicos, portanto, empregam essa linguagem, que, longe de ser inesperada em livros de teor religioso, é a regra nas apologéticas e polêmicas. No tempo da Reforma, eram famosas as gravuras dos panfletos antipapistas que, entre imagens licenciosas ou obscenas, mostravam lobos vestindo hábitos monacais. Também Lutero havia afirmado certa vez que todos os porcos da Bavária haviam se mudado

\footnotetext{
${ }^{27}$ Iohannis Calvini Opera Omnia. Series IV. Scripta didactica et polemica. Genève: Droz, 2007.
} 
para o curso de teologia da Faculdade de Ingolstadt, ${ }^{28}$ ao passo que Calvino havia dito que os anabatistas são como "porcos que reviram tudo com seus focinhos", enquanto "outros revoltam-se, como cães que retornam a seus vômitos e porcos a seus lodaçais". ${ }^{29}$ Ao comentar as Acta do Concílio de Trento, afirma ainda que seus membros "coaxam não sei que estridência, como as rãs de Aristófanes" ${ }^{\prime 30}$ e que, ao aceitarem o que ali foi decidido, "os asnos assentem com as orelhas".

Também Serveto usou imagens similares, em vários momentos. Por exemplo, ao comparar os monges, que andam em grupos em seus hábitos de cor marrom com capuzes, a "gafanhotos e outros animais gerados da podridão".

Tal é a natureza dos gafanhotos e de outros animais gerados na podridão, que gostam de temperatura e de locais quentes e úmidos, propícios à sua podridão. Reproduzem-se em quaisquer abrigos, em covas e buracos; amontoam-se à noite ou em tempo nublado e, uma vez nascido o sol, voam. (...) Se a um gafanhoto, dotado já de capuz pela natureza, vestires uma batina ou hábito monacal, terás um monge completo, um demônio disfarçado. (...) O poder da cauda desses gafanhotos é a falsa doutrina, como se fosse o veneno da cauda do escorpião. ${ }^{31}$

Em uma de suas críticas veementes ao batismo infantil, emprega a figura de linguagem euidentia quase que cinematograficamente, descrevendo movimentos com grande expressividade.

Há no Papado a Trindade do Dragão, da Besta e do Pseudoprofeta. A Trindade papística, constituem-na três espíritos realmente distintos, a que João, por muitas razões, chama "três espíritos imundos como rãs": porque, como as rãs, procedem das águas imundas do abismo e são, como as rãs, animais anfíbios; porque, no coaxar das rãs, balbuciam compassadamente trin-da-de; porque, pelo imundo poder desses três, com suas três qualidades infusas, o Papa batiza as rãs na imundícia. A água das rãs é imunda, e sua língua, presa. Daí que se chame a esse defeito da língua, batracoz, rã. Rã é aquele que, fazendo ruídos com a sua língua, não é capaz de exprimir sua fé. Rãs, portanto, batizam os papistas, com sua falsa fé na Trindade. Como rãs verás as criancinhas debatendo-se e berrando com o grito das rãs em seu pedobatismo. ${ }^{32}$

${ }^{28}$ Matheson 1998, 189.

${ }^{29}$ Institutio, 1541, XXXViii

${ }^{30}$ OC VII, 283.

${ }^{31}$ Ea est locustarum, et reliquorum ex putridine genitorum animalium natura, ut calidum et humidum ament tempus et locum, putridinis suae fomitem. In apricis quibusdam, sepibus et foueis generantur, nocturno seu nubiloso tempore coaceruantur, et orto postea sole uolant. (...) Si locustam, cui a natura est indita cuculla, induas lorica, seu monachali sacco, habebis integrum monachum, laruatum daemonem. (...) Potestas caudae harum locustarum est falsa doctrina quase scorpionis caudae uenenum. Christianismi Restitutio, 479-80.

${ }^{32}$ Trinitatem Papisticam faciunt tres realiter distincti spiritus, qui Ioanni dicuntur tres immundi spiritus ranarum, multis rationibus. Quia sunt de abyssi aquis immundis, sicut ranae: amphibia 
Num outro momento, o capítulo 34 de Isaías serve de ponto de partida para a comparação que estabelece entre "as bestas que rodeiam os escombros" e as ordens monásticas.

Habitam ali, diz (Isaías), corujas, mochos, morcegos, lâmias, corvos junto aos cadáveres, lobos que rondam o rebanho, gaviões e grifos, gordos porcos, cegas toupeiras, onagros, onocrotalos e onocentauros. Há, finalmente, o colégio dos abutres, para devorar os cadáveres, quando alguém morre. E esses abutres reclamam para si a presa, alternando-as com os corvos, os milhafres e outras bestas, por meio de cânticos em comum e de hinos que submurmuram sem que os entendam. E ainda diz que fariam para si ninhos, covas e casas onde veriam que há carnes gordas e gordos sacerdócios. ${ }^{33}$

Referências escatológicas são outra arma retórica, cuja intenção é criar uma atmosfera nauseabunda. Por isso, é frequente a associação da doutrina herética a dejetos, esgotos, pântanos, vômitos e imundícia em geral. Como exemplo, veja-se este passo de Calvino:

enfim, como um bêbado, depois de arrotar alto, lança fora o caldo imundo que jaz pesado em seu estômago, assim esses miseráveis, tendo vilipendiado o chamado sagrado que Nosso Senhor tanto estimou, vomitam finalmente em voz alta blasfêmias muito mais perturbadoras. ${ }^{34}$

Serveto usará de ironia escatológica ao zombar da eucaristia dos "magos e papistas", ridicularizando a ideia de que Cristo poderia habitar de fato no pão sem que, ingerido, passasse pelo processo por que passa todo alimento no corpo humano, até sua eliminação por meios naturais...

animalia, sicut ranae: quia ranarum glocitatione tres illi trinitatem concise balbucinant: quia eorum trium immunda uirtute cum tribos qualitatibus infusis ranas Papa baptizat in immunditia. Aqua est ranarum immunda, et língua earum est impedita. Vnde uitium linguae batracoz rana dicitur. Rana est, qui língua sonans nequit fidem suam exprimere. Ranas ita baptizant Papistae, falsa trinitatis fide. Ranarum instar paruulos ibi uideas calcitrantes, et ranarum clangore clamantes in paedobaptismo. Christianismi Restitutio, p. 463.

${ }^{33}$ Habitare ibi ait noctuas, ululas, vespertiliones, lamias, coruos ad cadauera, lupos circa gregem, accipitres, et gryphones: pingues porcos, caecas talpas, onagros, onocrotalos, et onocentauros. Denique miluorum collegium, quando aliquis moritur, ad cadauera deuoranda. Hosque miluos cum coruis, uulturibus, et aliis bestiis, per mútuos concentus, et sine intellectu submurmuratos odarum versículos, alternatim ad praedam sibi acclamantes. Imo, inquit, nidos, foueas et domos sibi facient, ubi uiderint esse pinguium carnes, et pinguia sacerdotia. Christianismi Restitutio, p. 482.

34 "en la fin, comme um yvrongne, apres avoir bien rotté, desgorgé le villain brouet qui luy charge l'estomac: ainsi ces malheureux, aprés avoir detracté de se sainct estat qui nostre Seigneur a tant honoré, vomissent finalement à pleine gorge des blasphemes beacoup plus desordonnés" (Calvin, Jean. Brieve instruction pour armer tous les bons fideles contre les erreurs de la secte commune des Anabaptistes.) 
Imaginam que a carne chega somente ao ventre, e daí desaparece ou se retira; dizem que, tão logo são recebidas no estômago as espécies de pão, Cristo migra, e não permanece ali. O que não é próprio de um alimento de verdade. ${ }^{35}$

Com isso, o cenário que o herege habita é evocado como uma cloaca, um local escuro e fétido, povoado de insetos e preenchido pelo mau cheiro do vômito ou das fezes. É ainda um mundo de trevas, com cheiro de morte. Já o verdadeiro cristão vive na luz, na companhia dos santos. Se o herege "revira o vômito com seu focinho", o cristão se aproxima calmamente da mesa da Ceia do Senhor. Ao comentar o pão e o vinho ofertados pelos fieis à mesa do Senhor, Serveto descreve este momento assim:

Esses dons eram oferecidos para a mesa do Senhor principalmente pelos mais ricos. Os presbíteros sentavam-se com os outros comensais, principalmente com os pobres, como narra Pôncio Paulino. ${ }^{36}$ Os ricos, com efeito, não devem ocupar na igreja um lugar mais destacado que os demais ( $\operatorname{Tg} 2$ ). Os diáconos os serviam, e eram admitidas também para esse serviço respeitáveis viúvas sexagenárias. Os próprios presbíteros, depois de pronunciadas a bênção e a ação de graças, eram os primeiros a partir o pão; em seguida, os outros o repartiam entre si, e todos se revigoravam com aquele símbolo da caridade, com aquela comida e bebida, todos feitos verdadeiramente partícipes do corpo e do sangue de Cristo. ${ }^{37}$

Diferentemente do universo caótico do herege, o mundo do cristão é ordenado e silencioso, preenchido apenas pelo suave perfume dos pães e pela suavidade das ações de graças.

Em outra comparação importante para este trabalho, compara-se o púlpito do orador ao palco de teatro. Defendemos que esta analogia pode se estender até mesmo à fogueira, sendo a atitude perante a morte uma espécie de discurso do mártir - um discurso, de resto, extraordinariamente persuasivo. Mas, no momento, importa-nos a atribuição de características de personagens a um ou outro, como a distribuição de papeis numa peça. Há, por exemplo, a personagem do "papista", quase sempre cômica, e que reúne em si as características do glutão ávido por dinheiro e entregue à sen-

\footnotetext{
${ }^{35}$ Imaginantur, carnem Christi in uentriculum solum demiti, deinde reuomi, seu abire. Cum primum assumptae sunt in stomacho species panis, aiunt migrare Christum, nec ibi manere. Quae non est ratio veri cibi. Christianismi Restitutio, p. 506.

${ }^{36}$ Diácono de Cipriano, escreveu sobre a vida deste bispo de Cartago, inaugurando, com este relato, o gênero "biografia cristã".

${ }^{37}$ Ad mensam domini haec offerebantur, praesertim a ditioribus. Sedebant presbyteri cum aliis sumpturis, praesertim pauperibus, ut refert Pontius Paulinus. Diuites enim non debent in ecclesia potiorem aliis locum tenere, Iaco.2. Seruiebant diaconi admissis etiam ad seruitium illud probatis uiduis sexagenariis. Presbyteri ipsi post dictam benedictionem, et gratiarum actionem, primi frangebant, deinde alii inter se diuidentes, omnes cibo illo et potu reficiebantur eo charitatis symbolo, vere facti participes corporis et sanguinis Christi. Christianismi Restitutio, pp. 710-11.
} 
sualidade, reproduzindo o estereótipo do católico, segundo a mentalidade do reformado. Atribuir ao outro um discurso é como pôr sobre ele uma persona do teatro antigo, como que lhe vestindo as roupas e a máscara que o identifiquem como herege, papista etc.

\section{CONCLUSÃO}

Se na visão renascentista e humanística a linguagem deveria espelhar a harmonia do cosmo, ${ }^{38}$ para o Cristianismo o século Xvi foi um tempo de desafio, turbulência e mesmo de combate, tanto contra os "hereges" como contra o Anticristo, numa batalha que haveria de ser a final. Essa linguagem, portanto, espelha a urgência da convocação para a luta e retrata o adversário de forma tão incisiva quanto caricatural. O recurso a imagens aparentemente hiper-realistas, como aquelas de insetos, por exemplo, são, na verdade, analogias por meio de descrições distorcidas do "outro", significativas em seu desequilíbrio. Na sátira e no panfleto, características cômicas são exageradas diante de um leitor que é convidado a desnaturalizar, pela hipérbole e pela ironia, aquilo que, pela familiaridade, se lhe tornara invisível (como, por exemplo, os hábitos monacais).

Por outro lado, ao tratar de si mesmo, é preciso evitar a todo custo a possibilidade de ser acusado de algo risível. Por isso, o orador cristão tentará colar à sua imagem características como a munditia, ou pureza de coração, e a humilitas. Tendo Cristo como fiador de seu discurso, ele mostra-se servil e obediente. Mas, claro está, se o ethos do enviado apresenta essa característica de total submissão perante aquele que o envia, exige, por outro lado, a total adesão por parte dos ouvintes; quem não aceitar o que ele diz não ofende a ele, mas a Deus...

Dentre muitas outras coisas dignas de menção, concluímos com algo que foi ponto central em nossas reflexões a respeito desta questão. É que, em tempos de perseguições e guerras religiosas, o autor cristão é também chamado a dar provas de sua convicção. E essa prova, no século XVI, podia variar de partir em exílio, com o rosto de "herege anabatista" marcado a ferro, a fogueira e torturas excruciantes. Houve naqueles tempos inquisitoriais tantos massacres e perseguições que surgiu algo como uma ars moriendi, uma arte do bem morrer, porque a morte pública, para dar testemunho, era também um discurso, e deveria ser o mais eficaz possível. Seria preciso

\footnotetext{
${ }^{38}$ Matheson 1998, 16.
} 
ainda estudar-se o quanto as descrições vívidas de martírios alimentaram a imaginação de novos mártires. Em todos os martirológios, são-nos oferecidas as mais vívidas descrições das torturas sofridas pelos santos, com o requinte das mais insuportáveis minúcias. Em que medida a écfrase desses tormentos era o combustível de uma visão de mundo que se fortaleceu precisamente em momentos em que se sofria o perigo do extermínio deverá ainda ser precisada. Estamos, aqui, trafegando entre mundos, naquela divisa entre discurso e vida, construção discursiva para persuadir o outro e convicção pessoal comprovada ao preço da própria vida. Miguel Serveto não evitou a morte na fogueira, e nossa premissa fundamental é que ele não o fez porque se havia investido plena e sinceramente do ethos que podemos depreender de seu texto. Ao estuda-lo, chegamos à conclusão de que a pesquisa acadêmica deve sem dúvida afastar-se do biografismo, mas talvez nem sempre deva perder de vista aquilo que, na história, é um dado, um evento. Algo a que o enviado chamaria um "testemunho".

\section{REFERÊNCIAS}

Servetus, Michael. 1966. Christianismi Restitutio. Totius ecclesiae apostolicae est ad sua limina uocatio, in integrum restituta cognitione Dei, fidei Christi, iustificationis nostrae, regenerationis baptismi, est coenae domini manducationis. Restitutio denique nobis regno caelesti, Babylonis impiae captiuitate soluta, et Antichristo cum suis penitus destructo. M.D.LIII. Fac-simile a partir da edição de von Mürr, de 1790. Frankfurt: Minerva.

Bainton, R. H. 1953. Hunted Heretic: the life and death of Michael Servetus, 1511-1553. Boston: Beacon Press.

Berger, Klaus. 1998. As formas literárias do Novo Testamento. Trad. de Fredericus Antonius Stein. Bíblica Loyola - 23. São Paulo: Ed. Loyola.

Castellio, S. 1612. Contra libellum Calvini in quo ostendere conatur haereticos jure gladij coercendos esse. Edição de Amsterdam, digitalizada e disponível em: http://gallica.bnf.fr/ark:/12148/bpt6k74037q/f2.image.langES.

Cohn, Norman. 1981. Na senda do Milênio. Milenaristas revolucionários e anarquistas místicos da Idade Média. Lisboa: Editorial Presença.

Estep, William R. 1978. The Anabaptist story. An introduction to sixteenth-century Anabaptism. Grand Rapids \& Cambridge: Williams B. Eerdmans Publishing Co.

Friedman, J. 1978. Michael Servetus: a case study in total heresy. Genève: Droz.

Kennedy, George A. 1998. Classical Rhetoric and its Christian and Secular Tradition. From AncienttoModernTimes. ChapelHill:TheUniversityofNorth CarolinaPress, 1998.

Klaasen, Walter. 1992. Living at the end of the ages. Apocalyptic expectation in the Radical Reformation. Lanham: University Press of America.

Hillar, M. 2002. Michael Servetus: Intellectual giant, humanist, and martyr. New York: University Press of America. 
Matheson, Peter. 1998. The Rhetoric of the Reformation. Edinburgh: T\&T Clark

Nakládalová, I., ed. 2013. Religion in Utopia. From More to Enlightenment. Sankt Augustin: Academia Verlag.

Naya, J.; Hillar, M, ed. 2011. Michael Servetus, Heartfelt: Proceedings of the International Congress, Barcelona, 20-21 October, 2006. New York: University Press of America.

Scott, I. 1910. Controversies over the imitation of Cicero as a model for style and some phases of their influence on the schools of the Renaissance. New York: Columbia University.

Tuck, R. 1993. Philosophy and government (1572 - 1651). Cambridge: Cambridge University Press.

Van Braght, Thieleman J. 1977. The Bloody Theater or Martyrs Mirror of the defenseless Christians who baptized only upon confession of faith, and who suffered and died for the testimony of Jesus, their Saviour, from the time of Christ to the year A.D. 1660 (translated from the original Dutch language from the edition of 1660 by Joseph F. Sohm). Scottdale, PA: Herald Press.

Williams, G.H. 1962. The Radical Reformation. Philadelphia: The Westminster Press.

\section{$*$}

Title. The construction of Christian self-image and the manufacture of the heretic in the polemics of the sixteenth century.

Abstract. The main goal of this paper is to understand the logic that guides the mechanisms of Polemics in Christian apologetical speeches and, having asserted that, to underline the rhetorical strategies with which the polemist builds and validates for himself the ethos both of a true Christian and of the "advocate of the Truth". Meanwhile, at the same time, he fabricates the image of the "enemy", the heretic, the "false master" for his adversary. In order to achieve that, we will comment on the techniques of appropriation of an auctoritas practiced by the author when he speaks about himself, along with the satirical aspects of the drawing of an "other" - a caricature whose goal is not only derision, but also exclusion. And we will do so using a "heretical" book, in which the author, a persecuted man himself, reproduces, notwithstanding, the same process employed by those who sought to establish an "official" religion. Our corpus is the heretical Christianismi Restitutio, by Michael Servetus, published in 1553.

Keywords. Rhetoric; ethos; 16th century; polemics; Michael Servetus. 